Niniejsza publikacja jest dostępna na licencji Creative Commons. Uznanie autorstwa-Użycie niekomercyjne-Bez utworów zależnych 3.0 Polska. Pewne prawa zastrzeżone na rzecz autora. Zezwala się na wykorzystanie publikacji zgodnie z licencja - pod warunkiem zachowania niniejszej informacji licencyjnej oraz wskazania autora jako właściciela praw do tekstu. Treść licencji jest dostępna na stronie: http://creativecommons.org/licenses/by-nc-nd/3.0/pl/

Lingwistyka Stosowana 19: 4/2016, 61-75

\author{
Jacek KARPIŃSKI \\ Uniwersytet Wrocławski
}

\title{
Komunikacja na pokładzie samolotu jako wyzwanie dla dydaktyki języków obcych
}

\begin{abstract}
:
On-board communication as a challenge for foreign language teaching

Cabin crew members are people who - contrary to common opinions - not only welcome the passengers on board or serve meals and drinks. Among the most important tasks of flight attendants is providing security on board. Thus, in (civil) aviation successful communication is undoubtedly one of the most significant aspects of providing safety during each flight and in emergency situations. However, one may have the impression that on-board communication is not typical and, what is more, it is even hindered by a number of factors such as passengers' behaviours (stress, no interest) or the fact that on-board announcements are usually broadcast in the language of a given airline or in English whereas the sender and receiver often come from diverse cultural backgrounds. What is also an important aspect is the specialisation of on-board announcements which are broadcast to people without any specialised knowledge of the topic. The paper presents the characteristic features of communication which takes place between cabin crew members and passengers. The author discusses the results of the analysis of various foreign language course books. After scanning them, one may claim that the topics of travelling on a plane and on-board communication are not within the scope of interest of teachers. Another relevant aspect is the fact that attention should be paid to the necessity to teach the vocabulary used on board. Of equal importance is the fact that other determinants of communication between cabin crew members and passengers as well as the manners of using them in the process of foreign language teaching/ learning should be taken into consideration.
\end{abstract}

\section{Wstęp}

Tuż po zakończeniu I wojny światowej startują w Europie pierwsze loty pasażerskie. $\mathrm{Z}$ biegiem czasu loty stają się szybsze, wygodniejsze i przede wszystkim bezpieczniejsze. W latach 30' XX wieku na pokładzie samolotu pojawia się także nowa osoba - stewardessa, która wbrew powszechnej opinii nie tylko wita pasażerów oraz serwuje napoje i posiłki, ale przede wszystkim dba o zapewnienie bezpieczeństwa na pokładzie i sprawną ewakuację w sytuacji awaryjnej.

Mimo że niektóre obowiązki personelu pokładowego zmieniły się z biegiem czasu $^{1}$, zapewnienie bezpieczeństwa było i jest od zawsze priorytetem. Pierwsze ste-

\footnotetext{
${ }^{1} \mathrm{~W}$ podręczniku dla personelu pokładowego z 1930 roku można znaleźć m.in. następujące
} 
wardessy były dyplomowanymi pielęgniarkami i, ubrane w jasnoszare fartuchy pielęgniarskie, opiekowały się pasażerami. Dzięki temu dawały im poczucie spokoju, bezpieczeństwa i pewności, że jest obok nich ktoś z medycznym wykształceniem zwłaszcza że choroba lokomocyjna była wówczas na porządku dziennym (zob. R.G. Grant 2003: 145).

W wyniku silnego rozwoju lotnictwa podczas II wojny światowej zrodziła się potrzeba stworzenia międzynarodowych standardów i procedur gwarantujących bezpieczeństwo na pokładzie oraz należyty rozwój lotnictwa. Dlatego też w roku 1944 na mocy Konwencji o międzynarodowym lotnictwie cywilnym (konwencji chicagowskiej) ustanowiono ICAO - Organizację Międzynarodowego Lotnictwa Cywilnego, odpowiedzialną za opracowywanie i wdrażanie przepisów gwarantujących bezpieczeństwo w lotnictwie.

Obecnie załogi pokładowe w programie swoich szkoleń mają przede wszystkim - obok problematyki dotyczącej obsługi pasażera czy serwisu pokładowego - zagadnienia związane z procedurami awaryjnymi (sprzęt awaryjny, zasady dobrze przeprowadzonej ewakuacji, zachowanie personelu w sytuacji awaryjnej, panowanie nad thumem) oraz komunikacją wśród członków załogi, stanowiącą w sytuacji awaryjnej podstawę sprawnej ewakuacji ( $C R M$ - crew resource management; zarządzanie zasobami załogi: współpraca w załodze, komunikacja wśród personelu, czynnik ludzki w lotnictwie). Ostatnie wydarzenia ${ }^{2}$ pokazały, że profesjonalizm personelu pokładowego i sprawna komunikacja mogą uratować życie setkom pasażerów.

Wraz z dołączeniem stewardess do załogi na pokładzie pojawił się także nowy problem dla językoznawców oraz glottodydaktyków, który do tej pory nie znalazł pogłębionego opracowania w literaturze naukowej - problem komunikacji załogi pokładowej z pasażerem (zarówno podczas rutynowych lotów, jak i w sytuacjach awaryjnych). Celem niniejszego artykułu jest zatem zwrócenie uwagi na specyfikę komunikacji na pokładzie samolotu między personelem pokładowym a pasażerem oraz przedstawienie jej wybranych aspektów. Pod dyskusję zostaną poddane także wyniki analizy wybranych podręczników do nauki języka polskiego i niderlandzkiego jako obcego pod kątem nauczania słownictwa stosowanego na pokładzie oraz uwzględniania innych determinantów komunikacji między personelem pokładowym a pasażerami. Następnie zostaną zaprezentowane sposoby włączenia tych treści w proces nauczania języka obcego i integrację z innymi treściami programowymi.

instrukcje: należy salutować zawsze, kiedy na pokład wchodzi pilot i pierwszy oficer; należy odcinać kupony z biletu podczas każdego międzylądowania; należy zaopatrzyć wszystkie bagaże w nalepkę i skontrolować bagaże na pokładzie samolotu; przed każdym lotem należy posprzątać samolot i sprawdzić, czy siedzenia są dobrze przykręcone; po starcie należy zabić wszystkie muchy. Zadaniem stewardessy było także odwiezienie na dworzec pasażerów, którzy nie mogli kontynuować podróży samolotem ze względu na jego awarię (zob. R.G. Grant 2003: 144).

${ }^{2} \mathrm{~Np}$. działanie załogi w przypadku lądowania na rzece Hudson samolotu A320 amerykańskich linii US Airways 15 stycznia 2009 r., lądowania ze schowanym podwoziem samolotu B767 PLL LOT na warszawskim Okęciu 1 listopada 2011 r. czy awaryjnego lądowania samolotu B777 linii Emirates w Dubaju 3 sierpnia 2016 r. 


\section{Komunikacja na pokładzie samolotu jako specyficzny rodzaj komunikacji}

Biorąc jako punkt wyjścia tradycyjny model komunikacji, w którym dwie osoby przekazują sobie pewne informacje i którego celem jest interakcja (nadawca informuje o czymś odbiorcę, który to z kolei reaguje na dany komunikat), można by stwierdzić, że do sprawnej komunikacji wystarczy wyłącznie znajomość danego języka. Jeśli nadawca i odbiorca będą mówić w tym samym języku, z pewnością dojdą do porozumienia. Przenosząc to podejście na płaszczyznę komunikacji specjalistycznej, można by zatem stwierdzić, że gwarantem sukcesu w takim przypadku jest, obok znajomości samego języka, znajomość terminologii fachowej. Z jednej strony nie ma się tu czemu dziwić, ponieważ dzięki terminom specjalistycznym, które $\mathrm{z}$ reguły są konkretne i jednoznaczne, specjaliści przekazują (sobie) najczęściej informacje pozbawione domysłów i niepewności. Terminologia jest też tym elementem języka specjalistycznego, na który położony jest największy nacisk w dydaktyce języków fachowych. $Z$ drugiej jednak strony rodzi się pytanie, czy sama znajomość języka i terminologii specjalistycznej wystarczy, aby w adekwatny sposób komunikować się z drugim człowiekiem. R. Appel (2002: 27) wychodzi z założenia, że kompetencja językowa jest bez wątpienia niezwykle istotna, ale zarówno nadawca, jak i odbiorca muszą posiadać jeszcze kompetencję komunikacyjną oraz określoną wiedzę na temat świata. Warto zauważyć także niezwykle istotną rolę kompetencji interkulturowej, której brak może negatywnie wpłynąć na proces komunikacji. Mając zatem na uwadze fakt, że do komunikacji niezbędne jest posiadanie tych kompetencji oraz to, że znajomość słownictwa fachowego nie wystarczy, gdyż język specjalistyczny, a co z tym związane także komunikacja specjalistyczna, determinowane są przez wiele innych elementów, zarówno językowych, jak i pozajęzykowych, warto spojrzeć na komunikację specjalistyczną nieco szerzej. Podejście to wpisuje się w aktualną dyskusję na temat badania języków specjalistycznych. S. Grucza (2008: 77) zauważa, że „historia zajmowania się językami specjalistycznymi jawi się jako proces ciągłego rozszerzania zakresu (...). W gruncie rzeczy novum każdego kolejnego etapu polegało na poszerzeniu dotychczasowej perspektywy oglądu rzeczywistości językowej, wniesieniu do dyskusji o niej nowych zagadnień i/ lub dodatkowych płaszczyzn."

W modelu procesu komunikacji zaproponowanym przez F.R. Oomkesa (2000) autor zwraca szczególną uwagę na sytuację, w której przekazywana jest pewna informacja oraz na ramy referencyjne nadawcy i odbiorcy. Istotnymi elementami procesu komunikacji są także - poza nadawcą, odbiorcą, przekazywaną informacją i sytuacją, w której ma to miejsce - kanał i sposób komunikacji, zakłócenia pojawiające się w tym kanale, kodowanie i dekodowanie przekazywanej informacji (tłumaczenie) oraz reakcja na daną informację (feedback). Poza tym F.R. Oomkes (2000: 36) przedstawia komunikację nie jako proces linearny lecz ciągły, w którym każdy uczestnik może być zarówno nadawcą, jak i odbiorcą. Tezę tę potwierdza F.F.O. Holzhauer (2006: 41) dodając, że procesy komunikacyjne mogą rozgrywać się wszędzie i mogą w nich brać udział różni ludzie oraz ilustrując to na trzech przykładach - komunikacji osobistej (nadawca przekazuje informację odbiorcy i oczekuje reakcji; zmiana ról), komunikacji grupowej (dyskusja, w której bierze udział kilka osób i każdy uczestnik jest 
nadawcą i odbiorcą) oraz komunikacji masowej (nadawca przekazuje komunikat grupie osób i niekoniecznie oczekuje reakcji).

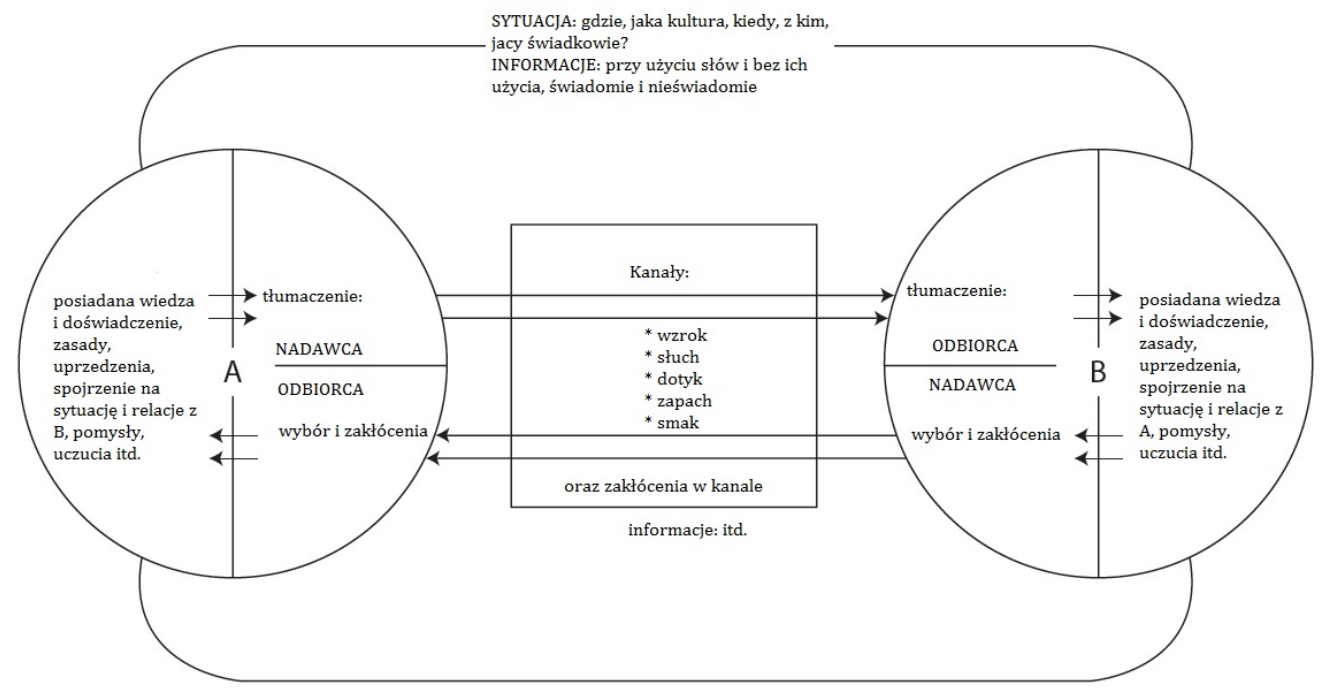

Rys. 1. Model procesu komunikacji - 'Het procesmodel van communicatie'

(F.R. Oomkes 2000: 36; ttum. JK)

Komunikacja na pokładzie samolotu między personelem pokładowym a pasażerem zdaje się doskonale wpisywać w ten model. Zarówno nadawca, jak i odbiorca posiadają określone spojrzenie na świat, pewną, charakterystyczną wyłącznie dla siebie, wiedzę i doświadczenie, swoje zasady i uprzedzenia, w typowy dla siebie sposób patrzą na daną sytuację. Ramy te wydają się niezwykle istotne, aby uporządkować otaczający nas świat i zrozumieć, że nadawca i odbiorca mogą te same sprawy postrzegać w całkowicie różny sposób. Poza tym nie można zapomnieć tu o specjalistycznej wiedzy, którą posiada personel pokładowy, a której nie musi mieć pasażer. Mimo to komunikacja ma szansę na powodzenie, jeśli jej uczestnicy wezmą pod uwagę ramy referencyjne drugiej osoby (zob. C. Muylle 2011: 57).

Komunikacja na pokładzie nie jest wyłącznie komunikacją werbalną. Niezwykle istotną rolę odgrywają liczne komunikaty niewerbalne, stosowane znaki indeksowe i ikoniczne. Informacja jest zatem przekazywana wieloma różnymi kanałami. Przykładem może być safety demo prezentowane na początku każdego lotu. Komunikat werbalny zawsze uzupełniony jest elementami niewerbalnymi. W ten sposób pasażerowie, którzy nie posiadają określonej wiedzy i często nie rozumieją danego języka, mają większą szansę na zrozumienie tego, o co chodzi i w jaki sposób należy postępować w sytuacji awaryjnej. Dlatego też np. podczas zapowiedzi na temat masek tlenowych załoga zawsze pokazuje - krok po kroku - jak tych masek się używa. W komunikacji na pokładzie wykorzystywanych jest także wiele ikon. Obrazy użyte m.in. na kartach bezpieczeństwa z reguły mówią same za siebie, są zrozumiałe przez przedstawicieli wielu różnych kultur (co w tak interkulturowym środowisku jak pokład samolotu jest niezwykle istotne) i w wielu przypadkach mają silniejsze i trwalsze 
działanie niż język mówiony. W.A. Pytel (2003: 66) zwraca uwagę na fakt, że znaki ikoniczne, np. ilustracje, umożliwiają niezwłoczne i dokładne przekazanie i odebranie treści, do czego w języku naturalnym potrzeba by było wielu słów i struktur.

Podczas komunikacji między załogą a pasażerem może pojawić się jednak wiele zakłóceń, które mogą wpłynąć negatywnie na cały proces. Mogą być to zarówno zakłócenia zewnętrzne (fizyczne), np. hałas na pokładzie samolotu, wadliwa lub zbyt cicho ustawiona aparatura; wewnętrzne (psychologiczne), np. stres pasażera, lęk przed podrożą samolotem, brak zainteresowania komunikatami przekazywanymi przez załogę; relacje między nadawcą a odbiorcą czy różnice interkulturowe oraz zakłócenia językowe, np. brak znajomości danego języka, 'lokalna' wymowa języka angielskiego czy charakterystyczne cechy morfosyntaktyczne zapowiedzi pokładowych (zob. J. Karpiński 2015a). Jako istotne zakłócenia w kanale komunikacyjnym można potraktować także „,nienaturalną często intonację, mówione teksty z licznymi elementami języka pisanego, automatyzację [rutynę] i monotonię zapowiedzi czy zniechęcenie w głosie [personelu pokładowego]" (J. Karpiński 2015a: 27).

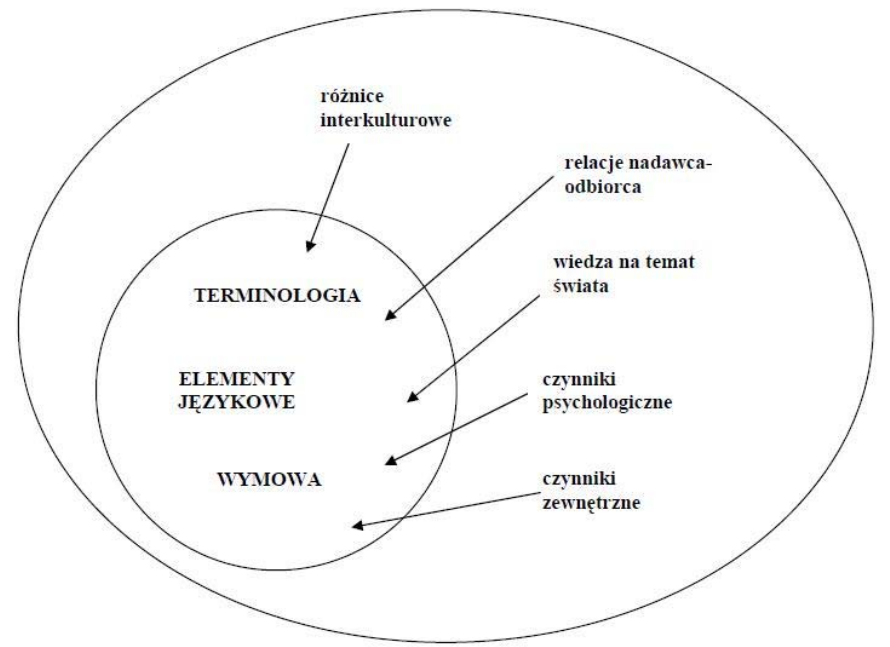

Rys. 2. Składowe i czynniki determinujące język awiacji/ Możliwe zakłócenia w procesie komunikacji (J. Karpiński 2015a: 28)

$\mathrm{Na}$ samej górze modelu procesu komunikacji zaproponowanego przez F.R. Oomkesa (2000: 36) znajduje się sytuacja komunikacyjna wyznaczająca swoistego rodzaju ramy, w których dana komunikacja się odbywa - gdzie, kiedy, z kim, w jakich warunkach (kulturowych). Wpływ tego elementu jest niezwykle istotny - różne sytuacje komunikacyjne wymagają różnych rejestrów, różnych środków przekazu i w zależności od np. miejsca czy tła kulturowego uczestnika mogą wyglądać całkiem odmiennie. Inaczej będzie wyglądała rozmowa na temat poczucia bezpieczeństwa w samolocie, kiedy siedzi się wygodnie przed telewizorem i wspomina ostatnie wakacje, a inaczej przebiegnie prezentacja zasad bezpieczeństwa przez personel pokładowy w 
sytuacji awaryjnej ${ }^{3}$.

Typowe sytuacje komunikacyjne, z którymi można się spotkać na pokładzie samolotu, zestawione zostały w poniższej tabeli:

\begin{tabular}{|c|c|}
\hline Boarding & $\begin{array}{l}\text { - powitanie } \\
\text { powitania formalne i nieformalne; znajomość i użycie zwrotów } \\
\text { grzecznościowych } \\
\text { - zajmowanie miejsc i umieszczanie bagażu w schowkach lub pod } \\
\text { fotelem } \\
\text { prośba o pomoc i wskazanie przydzielonego miejsca, rozwiązywa- } \\
\text { nie problemów z przydzielonymi miejscami; komfort i bezpieczeń- } \\
\text { stwo (dopinacze i przedłużacze pasów); umieszczanie bagażu w } \\
\text { schowkach lub pod siedzeniami, rozwiązywanie problemów z bra- } \\
\text { kiem miejsca w schowkach }\end{array}$ \\
\hline $\begin{array}{l}\text { Briefing pasaże- } \\
\text { rów i pozostałe za- } \\
\text { powiedzi pokła- } \\
\text { dowe }\end{array}$ & $\begin{array}{l}\text { - safety demo i zapoznanie z podstawowym sprzętem awaryjnym } \\
\text { rozumienie safety demo; zapoznanie ze sprzętem awaryjnym (pod- } \\
\text { stawowa terminologia); mówiony język pisany i trudność jego zro- } \\
\text { zumienia; czynniki zewnętrzne wpływające na zrozumienie zapo- } \\
\text { wiedzi (wadliwa aparatura, rutyna personelu pokładowego, stres pa- } \\
\text { sażera); środki ikoniczne i indeksowe ułatwiające zrozumienie ko- } \\
\text { munikatu } \\
\text { - pozostałe zapowiedzi pokładowe } i \text { postępowanie w sytuacjach } \\
\text { awaryjnych (drobne usterki, turbulencje, pożar na pokładzie, la- } \\
\text { dowanie awaryjne, wodowanie) } \\
\text { informowanie załogi o zauważonej usterce, dymie, pożarze na po- } \\
\text { kładzie (miejsce i rodzaj); rozumienie poleceń załogi (tryb rozkazu- } \\
\text { jący } \rightarrow \text { w sytuacji awaryjnej nie ma czasu na szczegółowe wyja- } \\
\text { śnianie czy tłumaczenie instrukcji na kilka języków: proste komu- } \\
\text { nikaty w języku angielskim, np. BRACE POSITION. GRAB YOUR } \\
\text { ANKLES, GET DOWN); sposób postępowania w sytuacjach awa- } \\
\text { ryjnych (terminologia związana ze sprzętem awaryjnym, np. maski } \\
\text { tlenowe, kamizelki ratunkowe, wyjścia ewakuacyjne); przeszkole- } \\
\text { nie ABP }\end{array}$ \\
\hline Serwis pokładowy & $\begin{array}{l}\text { - zamawianie positków i napojów } \\
\text { czytanie menu/ oferty cateringowej (napoje zimne i gorące, alko- } \\
\text { hole, przekąski, kanapki, dania ciepłe); zamawianie wybranych dań } \\
\text { i napojów; prośba o opis produktu } \\
\text { - zakupy na pokładzie }\end{array}$ \\
\hline
\end{tabular}

\footnotetext{
${ }^{3} \mathrm{~W}$ przypadku pełnego planowanego lądowania awaryjnego (jeśli do przyziemienia jest min. 10 minut), personel pokładowy ma obowiązek przeszkolić szczegółowo pasażerów oraz ABP (able-bodied passengers). ICAO definiuje ABP jako „passengers who are clearly physically able and are willing to help cabin crew maintain good order and discipline on board the aircraft." (ICAO 2014: xiv). ABP to najczęściej osoby, które zajmują miejsca przy wyjściach awaryjnych i komunikują się bez problemu w języku angielskim lub/ oraz języku danej linii lotniczej.
} 


\begin{tabular}{|c|c|}
\hline & $\begin{array}{l}\text { zakupy na pokładzie (perfumy i inne kosmetyki, gadżety, zegarki i } \\
\text { biżuteria, papierosy i alkohol); sposoby płatności; znajomość i uży- } \\
\text { cie zwrotów grzecznościowych }\end{array}$ \\
\hline Zdrowie & $\begin{array}{l}\text { - problemy zdrowotne na pokładzie } \\
\text { prośba o pomoc, opis dolegliwości (ze szczególnym zwróceniem } \\
\text { uwagi na sytuacje mogące wystąpić na pokładzie, np. zatkanie uszu, } \\
\text { duszność), znajomość nazw części ciała oraz objawów choroby } \\
\text { - udzielanie pierwszej pomocy } \\
\text { znajomość terminologii związanej z udzielaniem pierwszej pomocy }\end{array}$ \\
\hline $\begin{array}{l}\text { Lądowanie } \\
\text { i deboarding }\end{array}$ & $\begin{array}{l}\text { - pożegnanie } \\
\text { pożegnanie z załogą, podziękowanie za lot; zgłoszenie pozostawio- } \\
\text { nych przedmiotów na pokładzie }\end{array}$ \\
\hline Small talk & $\begin{array}{l}\text { - budowanie relacji z pasażerem, otwartość, rozładowanie atmos- } \\
\text { fery, poczucie bezpieczeństwa } \\
\text { krótkie rozmowy na popularne tematy, np. pogoda, wakacje, po- } \\
\text { dróże }\end{array}$ \\
\hline
\end{tabular}

Na uwagę zasługuje także fakt, że osoby komunikujące się ze sobą na pokładzie samolotu muszą w miarę swobodnie odbierać przekazywane informacje (rozumienie tekstów mówionych i pisanych), a także je tworzyć (produkcja tekstów mówionych, zdecydowanie rzadziej pisanych).

\section{Komunikacja na pokładzie samolotu w materiałach dydaktycznych}

Jeżeli zdamy sobie sprawę z faktu, że komunikacja na pokładzie samolotu między personelem pokładowym a pasażerem może być kluczowa dla zapewnienia bezpieczeństwa wszystkich lecących oraz weźmiemy pod uwagę fakt, że jest ona determinowana zarówno przez elementy językowe, jak i pozajęzykowe oraz że odbywa się wieloma kanałami, rodzą się istotne pytania:

- czy pasażerowie są w stanie bez problemu komunikować się z załogą pokładową w kwestiach związanych z bezpieczeństwem lotu (np. poinformowanie o dymie w toalecie czy zakomunikowanie problemów zdrowotnych), a także w innych sytuacjach na pokładzie (np. powitanie przy wsiadaniu na pokład samolotu, krótka rozmowa podczas wyboru posiłku czy chowania bagażu w schowkach nad głowami);

- czy pasażerowie rozumieją bez problemu komunikaty personelu pokładowego - zarówno te związane z bezpieczeństwem (np. safety demo, procedury awaryjne), jak i te podczas rutynowego lotu (np. small talk, wybór posiłku);

- czy elementy komunikacji na pokładzie znalazły swoje miejsce w podręcznikach do nauki języków obcych (mając na uwadze fakt, że część lotów odbywa się na pokładach samolotów linii, których języka nie znamy/ uczymy się);

- czy nauczyciele języków obcych zwracają podczas swoich lekcji uwagę na istotne aspekty komunikacji na pokładzie oraz rozwijają umiejętności niezbędne do działania w sytuacjach nietypowych (np. rozumienie tekstu, który ciężko zrozumieć ze względu na wadliwą aparaturę czy nieprawidłową intonację nadawcy, prowadzenie rozmowy w sytuacjach stresowych itp.). 
Aby znaleźć odpowiedź na niektóre z tych pytań, przeanalizowane zostały dwie metody dydaktyczne - Help! - kurs języka niderlandzkiego dla osób dorosłych oraz porównywalny z nim kurs języka polskiego Hurra!! Po polsku ${ }^{4}$. Oba kursy skierowane są do wykształconych, znających alfabet łaciński osób dorosłych i prowadzą studiujących do osiągnięcia poziomu B2 wg. poziomów biegłości językowej ESOKJ. Zarówno Help! jak i Hurra!! Po polsku składają się z trzech części, a ich uzupełnienie stanowią płyty CD i podręcznik dla nauczyciela. W obu kursach język traktowany jest jako środek do komunikacji, a przygotowane ćwiczenia obejmują typowe sytuacje z życia każdego człowieka, a na dalszych etapach nauki główne problemy współczesnego świata. Można by się więc spodziewać, że problematyka podróży lotniczych znajdzie swoje miejsce w analizowanych materiałach dydaktycznych.

Z analizy wszystkich trzech części podręcznika Help! wynika jednak wyraźnie, że podróż samolotem nie stanowi przedmiotu zainteresowania jego autorów. Żaden $\mathrm{z}$ rozdziałów (także rozdział 11 części 1: „Op reis” [W podróży - tłum. JK]) nie porusza w sposób dosłowny tej tematyki. W pierwszej części jednostki studenci poznają jedynie siedem słów luźno związanych z lotnictwem (douane, koffer, vliegtuig, bagage, luchthaven, paspoort i inchecken [służba celna, walizka, samolot, bagaż, lotnisko, paszport i odprawiać się - tłum. JK] a następnie muszą odpowiedzieć na pytanie, czy podróżowali już kiedyś samolotem - jeśli tak to dokąd i dlaczego, jeśli nie - jak podróżują najczęściej. W lekcji 12 natomiast, której głównym celem jest wprowadzenie czasu przeszłego w języku niderlandzkim, studenci konfrontowani są z krótkim tekstem „Vliegtuigje stort neer: vier doden” [Katastrofa małego samolotu: cztery ofiary śmiertelne - tłum. JK]. Mimo, że problematyka katastrof lotniczych, a co za tym idzie zapewnienia bezpieczeństwa na pokładzie, jest niezwykle istotna, zaprezentowany tu tekst jest jedynie punktem wyjścia do zastanowienia się nad strukturami gramatycznymi języka. Studenci muszą odpowiedzieć dodatkowo na dwa krótkie pytania do tekstu - ile osób znajdowało się na pokładzie samolotu i skąd ten samolot leciał. Pytania te w żaden sposób nie wymagają znajomości słownictwa związanego z podróżą samolotem i nie sprawdzają tak na dobrą sprawę zrozumienia całego tekstu (zob. J. Karpiński 2015b: 171). Druga część podręcznika Help! jest jeszcze uboższa, jeśli chodzi o problematykę lotniczą - nie pojawia się tu nic tematycznie z nią związanego. W części trzeciej natomiast zawarte są trzy teksty - jeden na temat opóźnionego lotu, będący ćwiczeniem gramatycznym sprawdzającym znajomość szyku w zdaniu - należy bowiem połączyć zdania odpowiednimi spójnikami. Dwa pozostałe to teksty na rozumienie ze słuchu - pierwszy na temat przeglądu samolotów (do którego sformu-

\footnotetext{
${ }^{4}$ Analizowane podręczniki to Help! do nauki języka niderlandzkiego: Ham, E./ Tersteeg, W. et al. (2004), Help! 1. Kunt u mij helpen? Boek voor de cursist, Utrecht; Ham, E./ Tersteeg, W. et al. (2003), Help! 2. Helpt u mij even? Boek voor de cursist, Utrecht; Dumon Tak, B./ Fontein, M. et al. (2002), Help! 3. Zal ik u even helpen? Boek voor de cursist, Utrecht; oraz Hurra!! Po polsku do nauki języka polskiego: Małolepszy, M./ Szymkiewicz, A. (2006), Hurra!! Po polsku 1. Podręcznik studenta, Kraków; Burkat, A./ Jasińska, A. (2007), Hurra!! Po polsku 2. Podręcznik studenta, Kraków; Burkat, A./ Jasińska, A. et al. (2009), Hurra!! Po polsku 3. Podręcznik studenta, Kraków
} 
łowano kilka pytań wielokrotnego wyboru), drugi o strajku kontrolerów lotu w Brukseli (po przeczytaniu którego należy podać jeden powód tego strajku). Z analizy podręcznika Help! wynika wyraźnie, że tematyka podróży samolotem nie znalazła swojego miejsca w tej metodzie. Można się jednak zastanowić, czy jakieś treści tematycznie związane $\mathrm{z}$ lotnictwem i mogące ułatwić komunikację na pokładzie zostały zintegrowane $\mathrm{z}$ innymi.

\begin{tabular}{|c|l|}
\hline Boarding & $\begin{array}{l}\text { zwrócenie uwagi na różne sposoby powitania (zarówno } \\
\text { formalne, jak i nieformalne) - liczne dialogi we wszyst- } \\
\text { kich trzech częściach podręcznika }\end{array}$ \\
\hline $\begin{array}{c}\text { Briefing pasażerów i po- } \\
\text { zostałe zapowiedzi po- } \\
\text { kładowe }\end{array}$ & -------------- \\
\hline Serwis pokładowy & $\begin{array}{l}\text { mówienie o potrzebach, zamawianie posiłków w restau- } \\
\text { racji (częściowo można przenieść to na pokład samo- } \\
\text { lotu); nazwy produktów żywnościowych w cz. 1, lekcja } \\
7 \text { 'Winkelen' [Robienie zakupów - tłum. JK], robienie } \\
\text { zakupów }\end{array}$ \\
\hline Zdrowie & $\begin{array}{l}\text { podstawowe objawy chorobowe (katar, kaszel, ból gar- } \\
\text { dła itp.), które częściowo mogą mieć zastosowanie na } \\
\text { pokładzie; rozmowa z lekarzem }\end{array}$ \\
\hline $\begin{array}{c}\text { Lądowanie } \\
\text { I deboarding }\end{array}$ & $\begin{array}{l}\text { zwrócenie uwagi na różne sposoby żegnania się (for- } \\
\text { malne i nieformalne) }\end{array}$ \\
\hline Small talk & $\begin{array}{l}\text { podręcznik oferuje sporo tekstów, które z powodzeniem } \\
\text { można wykorzystać do swobodnej, niezobowiązującej } \\
\text { rozmowy na pokładzie, czy to z załogą, czy ze współpa- } \\
\text { sażerem (np. zapoznanie, cz. 1, lekcja 2; podróże, cz. 1, } \\
\text { lekcja 11; pogoda, cz. 2, lekcja 2) }\end{array}$ \\
\hline
\end{tabular}

Z powyższej tabeli wynika, że kursant uczący się języka niderlandzkiego z podręcznika Help! powinien poradzić sobie bez większego problemu podczas rutynowego lotu: przywita się w adekwatny sposób z personelem pokładowym, zamówi lub wybierze dla siebie posiłek i napój, a po zakończonym locie, wysiadając z samolotu, pożegna się z załogą. Problem może się pojawić w jakiejkolwiek sytuacji awaryjnej. Mimo że w metodzie Help! zwraca się kilkukrotnie uwagę na tematy związane ze zdrowiem, brak jest terminologii dotyczącej dolegliwości, które mogą pojawić się na pokładzie samolotu, np. ból uszu, duszności czy trudności z wyrównaniem ciśnienia. Istnieje także duże ryzyko, że pasażer mógłby mieć problem z poinformowaniem załogi o zauważonej usterce (dymie, specyficznym zapachu itp.), a co z tym związane, sprawnym działaniem w sytuacji awaryjnej.

Zastanawia także fakt, że w podręczniku Help! nie poświęcono odpowiedniej uwagi kwestiom bezpieczeństwa na pokładzie (w czasach kiedy samoloty stały się jednym z najpopularniejszych środków transportu), a pojawiają się tematy mające najprawdopodobniej uatrakcyjnić uczenie się języka, które nie wnoszą zbyt wiele do ogólnej wiedzy studiującego i nie rozwijają słownictwa, którego można by użyć w 
sytuacjach codziennych. Stąd też Help! proponuje studiującym teksty na temat stopnia zakrzywienia bananów czy też wspomnienia pewnego włamywacza.

Dość podobnie sytuacja wygląda w podręczniku do nauki języka polskiego jako obcego Hurra!! Po polsku!, jednak tutaj w kilku miejscach tematyka podróży samolotem pojawia się w sposób bardziej bezpośredni. Podobnie jak w podręczniku Help!, w cz. 1 znajduje się jedno ćwiczenie, w którym studiujący muszą odpowiedzieć na pytanie dotyczące sposobów podróżowania - Czym wolisz podróżować - samochodem, pociagiem czy może samolotem - a może autostopem? Dlaczego? Pytanie to, mimo że zmusza do krótkiej dyskusji, nie wnosi zbyt wiele do zwiększenia umiejętności i kompetencji ucznia $\mathrm{W}$ sytuacji na pokładzie samolotu. W cz. 1 pojawia się jeszcze jedno ćwiczenie - tym razem sprawdzające rozumienie tekstu pisanego. Zadaniem studentów jest przeczytanie kilku krótkich dialogów i zadecydowanie, gdzie rozmawiają ze sobą bohaterowie. Dwie z tych rozmów rozgrywają się (teoretycznie) na lotnisku. Nauczyciel mógłby potencjalnie potraktować te dialogi jako punkt wyjścia do rozmowy na temat odprawy biletowo-bagażowej, zachowania się na lotnisku czy podczas boardingu, jednakże $\mathrm{w}$ tekstach tych pojawią się liczne błędy logiczne $\mathrm{i}$ brak jakiejkolwiek spójności:

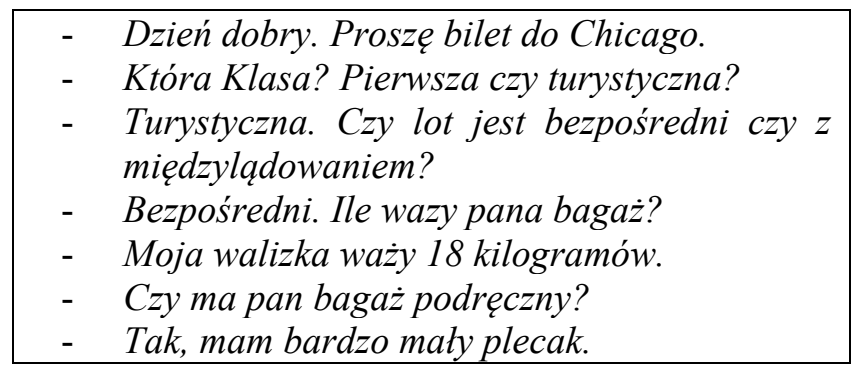

Rys. 3. Tekst z Hurra!! Po polsku, cz. 1, str. 110

W tej krótkiej wymianie zdań pomieszane zostały dwie sytuacje komunikacyjne - zakup biletu i odprawa biletowo-bagażowa przed lotem. Kupno biletu (już z walizką) na lotnisku zdarza się sporadycznie, ale uważnego ucznia zastanowi, gdzie tak na dobrą sprawę rozgrywa się ta sytuacja - czy mamy tu do czynienia z kupnem biletu przy stanowisku odprawy czy z odprawą w kasie biletowej. Żadna z tych sytuacji nie ma jednak miejsca w realnym świecie. Błędna jest także użyta tu terminologia - klasa pierwsza vs. klasa turystyczna. Zdecydowana większość linii lotniczych stosuje podział na klasę pierwszą, biznes i ekonomiczną, niektóre nazywają je dodatkowo charakterystycznymi dla siebie określeniami, np. Royal First Class, Royal Silk Class i Economy Class w Thai Airways. Dodatkowo postawione w tekście pytanie Ile waży pana bagaż? i precyzyjna odpowiedź pasażera: Moja walizka waży 18 kilogramów wydają się całkowicie oderwane od rzeczywistości. Zważenie bagażu jest obowiązkiem agenta obsługi pasażerskiej. Druga część podręcznika oferuje znacznie mniej tematyki lotniczej. Pojawia się tu jedno ćwiczenie, w którym należy wysłuchać tekstu (na szczęście już poprawnego merytorycznie) i uzupełnić zdania. W części trzeciej także znalazło swoje miejsce jedno 
ćwiczenie związane z lotnictwem - zadanie, w którym należy wysłuchać fragmentu artykułu i uzupełnić brakujące elementy tekstu. Samo zadanie nie jest wprawdzie zbyt dużym wyzwaniem dla uczącego się, wystarczy bowiem usłyszeć słowo i wpisać je w lukę, ale wykorzystany tekst jest dość ciekawy i zawiera stosunkowo dużo informacji, które mogą się przydać w czasie planowania podróży samolotem, np. co mieści w sobie ponoszona przez nas opłata i czego nie należy się spodziewać na pokładzie samolotów należących do przewoźników niskokosztowych. Na uwagę zasługuje też fakt, że jest to autentyczny tekst z Gazety Wyborczej, który z powodzeniem został zdydaktyzowany.

Analiza podręcznika Hurra!! Po polsku wykazała, że podróż samolotem nie stanowi przedmiotu zainteresowania autorów. Niektóre treści podręcznika można jednak wykorzystać podczas lotu samolotem.

\begin{tabular}{|c|c|}
\hline Boarding & $\begin{array}{l}\text { formuły powitalne wprowadzone w pierwszej lekcji, wyko- } \\
\text { rzystywane w większości dialogów we wszystkich czę- } \\
\text { ściach podręcznika; zwrócenie uwagi na styl oficjalny i } \\
\text { nieoficjalny }\end{array}$ \\
\hline $\begin{array}{l}\text { Briefing pasażerów i po- } \\
\text { zostałe zapowiedzi pokła- } \\
\text { dowe }\end{array}$ & $\begin{array}{l}\text { wypadki (relacjonowanie sytuacji z życia codziennego, np. } \\
\text { winda nie działa, nie ma wody, gaz się ulatnia, pali się) w } \\
\text { cz. } 3 \text {, lekcja } 13\end{array}$ \\
\hline Serwis pokładowy & $\begin{array}{l}\text { sytuacje w kawiarni i restauracji; nazwy potraw i produk- } \\
\text { tów żywnościowych; zakupy w sklepie spożywczym, wy- } \\
\text { rażanie preferencji }\end{array}$ \\
\hline Zdrowie & $\begin{array}{l}\text { nazwy części ciała, nazwy objawów choroby, dialogi u le- } \\
\text { karza (częściowo do wykorzystania na pokładzie samolotu) }\end{array}$ \\
\hline $\begin{array}{l}\text { Lądowanie } \\
\text { I deboarding }\end{array}$ & formuły pożegnalne w licznych dialogach \\
\hline Small talk & $\begin{array}{l}\text { podręcznik oferuje sporo tekstów, które z powodzeniem } \\
\text { można wykorzystać do swobodnej, niezobowiązującej roz- } \\
\text { mowy na pokładzie, czy to z załogą, czy ze współpasaże- } \\
\text { rem (np. opowiadanie o hobby, cz. 1, lekcja 5; podróże, cz. } \\
\text { 1, lekcja 13; formy spędzania wolnego czasu, cz. 2, lekcja } \\
\text { 14) }\end{array}$ \\
\hline
\end{tabular}

Podobnie, jak w przypadku podręcznika Help!, uczeń korzystający z Hurra!! Po polsku powinien poradzić sobie bez większego problemu podczas rutynowego lotu. Można założyć, że przywita się i pożegna z załogą w adekwatny sposób, zamówi wybrane jedzenie, porozmawia ze współpasażerem o pogodzie i interesujących go sprawach. W sytuacjach awaryjnych może jednak mieć problem. Wprawdzie w podręczniku autorzy zwracają uwagę na różne wypadki i awarie, które mogą mieć miejsce w codziennym życiu, ale nie skupiają się na sytuacjach, które mogą się wydarzyć podczas podróży samolotem. Uczeń jednak najprawdopodobniej byłby w stanie poinformować załogę o pożarze czy specyficznym zapachu. Podobnie jest z problemami zdrowotnymi wprawdzie jest kilka lekcji poświęconych wizycie u lekarza, opisywaniu objawów i mówieniu o stanie zdrowia, ale nie wprowadzono terminologii, która mogłaby się przydać na pokładzie samolotu. 
Z analizy podręcznika Hurra!! Po polsku wynika także, że autorzy sięgają po niektóre tematy, które z małym prawdopodobieństwem zostaną wykorzystane przez uczących się w codziennych sytuacjach, np. czystość gleb na Śląsku czy członkostwo w organizacji ochrony srok, sikorek i dzięciołów. Brakuje natomiast wielu kwestii, które mogłyby poprawić bezpieczeństwo podczas lotu.

\section{Komunikacja na pokładzie samolotu a wyzwania dla wspólczesnej dydaktyki języków obcych}

Jeżeli przyjmiemy, że efektywna komunikacja na pokładzie jest jednym z najważniejszych aspektów gwarantujących bezpieczeństwo podczas każdego lotu i w sytuacjach awaryjnych, powinna ona - zwłaszcza w czasach kiedy podróże samolotem są powszechnie dostępne - znaleźć stałe miejsce w dydaktyce języków obcych ${ }^{5}$. Na co więc zwrócić szczególną uwagę, wychodząc z założenia, że aby komunikować się z drugą osobą w adekwatny sposób, niezbędne jest nie tylko wykształcenie kompetencji językowej, komunikacyjnej i interkulturowej, ale także posiadanie określonej wiedzy na temat otaczającego nas świata, pewnych umiejętności i sprawności? Nie można także zapomnieć o zakłóceniach, które mogą pojawić się w kanale komunikacyjnym i z którymi powinny zmierzyć się osoby uczące się języka oraz o ramach referencyjnych nadawcy i odbiorcy w procesie komunikacji.

Rozwijanie kompetencji językowej to bez wątpienia zwrócenie szczególnej uwagi na terminologię specjalistyczną. Warto zatem skupić się na podstawowych pojęciach związanych z wyposażeniem i budową samolotu oraz możliwymi sytuacjami awaryjnymi (np. miejsce przy przejściu, miejsce przy oknie, pasy bezpieczeństwa, maski tlenowe, personel pokładowy, wyjście ewakuacyjne, turbulencja, dekompresja itp.). Analizując jednak język używany w awiacji (zob. J. Karpiński 2012, J. Karpiński 2015a, J. Karpiński 2015b) nie można pominąć także charakterystycznych cech morfosyntaktycznych. W dydaktyce języka niderlandzkiego szczególna uwaga powinna być więc skierowana przede wszystkim na dostosowywanie anglicyzmów do systemu języka niderlandzkiego - określanie rodzaju rzeczowników angielskich (np. de boarding card analogicznie do de kaart), tworzenie liczby mnogiej i zdrobnień (np. nie stewardesses jak $\mathrm{w}$ języku angielskim ale stewardessen zgodnie $\mathrm{z}$ niderlandzkimi wzorcami odmiany), odmianę i stopniowanie przymiotników angielskich (np. coolcooler-het coolst), odmianę czasowników angielskich (np. odmiana czasownika boarden w czasie teraźniejszym: ik board, jij boardt, hij/ zij/ het boardt, wij boarden, jullie boarden, zij boarden) i tworzenie od nich trzech form (np. boarden-boardde- $h$. geboard) (zob. J. Karpiński 2015a: 26). Treści te bez problemu można włączyć do istniejących już ćwiczeń gramatycznych a umiejętność ta przyda się także w innych

\footnotetext{
${ }^{5}$ Elementy komunikacji na pokładzie (z dużym naciskiem na kwestie bezpieczeństwa - postępowanie w sytuacjach awaryjnych, terminologia związana ze sprzętem awaryjnym) powinny z całą pewnością pojawiać się na kursach języka angielskiego (jako że angielski jest językiem lotnictwa), ale mając na uwadze fakt, że na pokładach samolotu słyszy się poza językiem angielskim najczęściej język danej linii lotniczej, powinny znaleźć swoje miejsce w programach kursów wszystkich współcześnie używanych języków.
} 
dziedzinach życia codziennego, które przesycone są zapożyczeniami z języka angielskiego, np. turystyka, marketing, język młodzieży. Z rozwijaniem kompetencji językowej związane jest też ściśle rozwijanie sprawności receptywnych i produktywnych (w szczególności rozumienia tekstów słuchanych i mówienie) oraz umiejętności radzenia sobie w sytuacjach „niewygodnych”, np. pracy z tekstem mówionym, w którym niektóre fragmenty są ściszone lub niewyraźne. Powinno wykształcić to w uczniach m.in. zdolność przewidywania dalszych treści czy rozumienia sensu tekstu przy uwzględnieniu całego kontekstu. Warto pracować także z autentycznymi tekstami, w których można usłyszeć osoby mówiące dość szybko czy używające mówionego języka pisanego. Niezwykle istotne wydaje się także uwrażliwienie studentów na niestandardowe, często błędne, akcenty i umiejętność radzenia sobie ze zrozumieniem takich tekstów.

Rozwijanie kompetencji komunikacyjnej w dydaktyce języka obcego to przede wszystkim zwrócenie uwagi na różne sytuacje, które mogą wystąpić na pokładzie samolotu i umiejscowienie ich w szerszym kontekście. Bez wątpienia w centrum zainteresowania powinna znaleźć się rola i pozycja nadawcy i odbiorcy, a uczniowie powinni umieć określić i zastosować właściwy rejestr dla danej sytuacji. Należy więc pracować z tekstami zarówno formalnymi, jak i potocznymi, zwracać uwagę na różnice między nimi oraz na problemy komunikacyjne, które mogą wystąpić, gdy nie zachowa się właściwej formy. Z kompetencją komunikacyjną ściśle związana jest także kompetencja interkulturowa. Warto więc mieć tu także na uwadze różnice między kulturami. O ile dla mieszkańca Nigerii zdanie You give me coke, you! wypowiedziane podczas serwisu pokładowego brzmi całkiem normalnie i może świadczyć o respekcie, którym darzy drugą osobę, o tyle dla Polaka zdanie Daj mi colę, ty! byłoby całkowicie nie do przyjęcia w tej sytuacji. Różnice międzykulturowe, na które warto zwracać uwagę na lekcjach języków obcych, związane są także z samym zachowaniem, które w niektórych kulturach jest oczywiste, a w innych może zostać odebrane niewłaściwie. Przykładem może być chociażby pstrykanie palcami u mieszkańców Meksyku w celu zwrócenia na siebie uwagi, które jest raczej nie do przyjęcia wśród mieszkańców Belgii (zob. A. van Veelen 2009: 193). Z kompetencją komunikacyjną i interkulturową związane jest także ściśle otwarcie na drugiego człowieka, zaakceptowanie innych ram referencyjnych, w których ten funkcjonuje, poszanowanie jego wiedzy i doświadczenia, jego wartości, uczuć i emocji.

W dydaktyce języka obcego nie może zabraknąć także elementów wiedzy na temat świata. W kontekście komunikacji na pokładzie warto zwrócić uwagę na przebieg samego lotu, pewne standardowe procedury oraz rolę poszczególnych członków załogi - stewardess i pilotów. Mając na uwadze bezpieczeństwo oraz fakt, że niektóre aspekty komunikacji załogi z pasażerem określone są w międzynarodowych przepisach, dobrze byłoby poświęcić im trochę więcej czasu w procesie dydaktycznym. Zgodnie z zasadami ICAO pasażer przed każdym lotem musi zostać zapoznany z wy- 
posażeniem awaryjnym samolotu - pasami bezpieczeństwa, wyjściami ewakuacyjnymi, kamizelkami ratunkowymi, maskami tlenowymi i kartami bezpieczeństwa ${ }^{6}$. Aby ułatwić zrozumienie tych zasad prezentowanych na początku każdego lotu, wiedza na ich temat oraz przydatna terminologia powinna pojawić się w programach kursów języków obcych.

Na komunikację na pokładzie samolotu w dydaktyce języków obcych można zatem spojrzeć jak na wielki worek, do którego należy włożyć mnóstwo treści, żeby była ona udana. Jednak jest to też worek, $\mathrm{z}$ którego z powodzeniem można i należałoby czerpać $\mathrm{w}$ wielu innych sytuacjach.

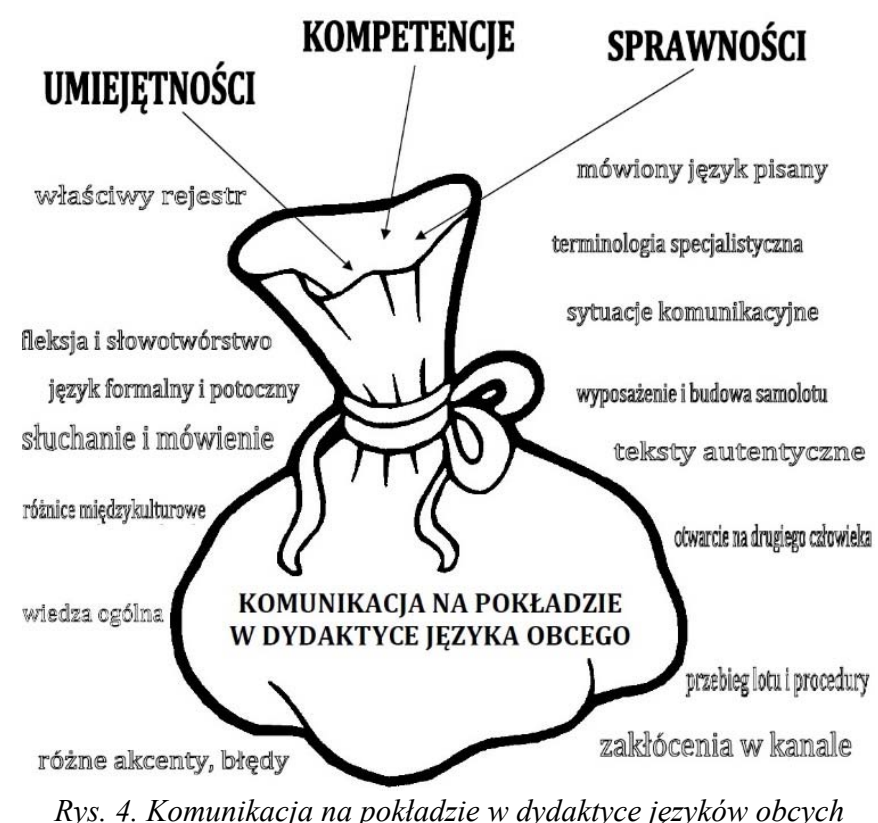

Wiele treści przydatnych na pokładzie samolotu można bez najmniejszego problemu zintegrować z kwestiami poruszanymi już obecnie w podręcznikach. Podczas lekcji na temat objawów chorobowych i wizyty u lekarza można przenieść jedną sytuację na pokład samolotu i wprowadzić terminologię związaną z zatkaniem uszu czy stresem przed podróżą. Lekcja, w trakcie której uczniowie poznają produkty spożywcze czy ćwiczą sytuacje komunikacyjne w restauracji, może także spokojnie zostać wzbogacona o mały aspekt pokładowy. Obok pojawiających się w każdej metodzie sytuacji na dworcu i kupowaniu biletu na pociąg, można poświęcić jedną lekcję na zapoznanie uczniów z sytuacją na lotnisku i na pokładzie samolotu oraz zwrócić uwagę na wybrane, najważniejsze aspekty lotu i bezpieczeństwa.

${ }^{6}, 4.2 .12 .1$. An operator shall ensure that passengers are made familiar with the location and use of: a) seat belts; b) emergency exits; c) life jackets, if the carriage of life jackets is prescribed; d) oxygen dispensing equipment, if the provision of oxygen for the use of passengers is prescribed; and e) other emergency equipment provided for individual use, including passenger emergency briefing cards.“ (ICAO 2010: 55-56) 
Komunikacja na pokładzie daje także wiele możliwości wykorzystania jej niektórych aspektów w ogólnym kształceniu językowym. Wykorzystując np. karty bezpieczeństwa, na których przedstawiony jest sposób zakładania kamizelki ratunkowej, można ćwiczyć umiejętność formułowania (ustnie i pisemnie) dłuższych tekstów, relacjonowanie czy spójność wypowiedzi. Gazetki pokładowe oraz oferty sprzedaży wolnocłowej są doskonałym źródłem nowych wyrazów, które z powodzeniem mogą wzbogacić słownictwo uczniów i zostać wykorzystane w innych sytuacjach codziennych. Warto więc pójść krok do przodu i uzupełnić swoje lekcje o aspekt lotniczy zarówno w celu lepszego funkcjonowania na pokładzie samolotu, jak i w celu zapewnienia większego bezpieczeństwa podczas lotu.

\section{Bibliografia}

Appel, R. et al. (red.) (2002), Taal en taalwetenschap. Oxford.

Ellis, S./ Lansford, L. (2010), English for Cabin Crew. Oxford.

Emery, H./ Roberts, A. (2008), Aviation English for ICAO compliance. Oxford.

Gerighty, T./ Davis, S. (2011), English for Cabin Crew. Hampshire.

Grant, R.G. (2003), Vliegen. Een eeuw luchtvaart, Tielt/ Utrecht (wydanie w niderlandzkiej wersji językowej)

Grucza, S. (2008), Lingwistyka języków specjalistycznych. Warszawa.

Holzhauer, F.F.O. et al. (2006), Communicatie. Theorie en praktijk. Den Haag.

ICAO (2010), International Standards and Recommended Practices. Annex 6 to the Convention on International Civil Aviation. Operation of Aircraft. Part I: International Commercial Air Transport-Aeroplanes, Montreal.

ICAO (2014), Cabin Crew Safety Training Manual, Doc. 10002 AN/502, Montreal.

Karpiński, J. (2012), Door Lage Landen en hoge heuvels... Hoe Nederlands is de Nederlandse luchtvaartterminologie, (w:) J. Novaković-Lopušina et al. (red.), Lage Landen, Hoge Heuvels. Handelingen Regionaal Colloquium Neerlandicum Belgrado. Belgrad, 307-315.

Karpiński, J. (2015a), Aviation Dutch? Próba definicji, (w:) Lingwistyka Stosowana/ Applied Linguistics/ Angewandte Linguistik, 15, (4/2015), 21-31.

Karpiński, J. (2015b), Op de luchthaven oftewel over de luchtvaarttaal in de NVTdidactiek, (w:) Brünner Beiträge zur Germanistik und Nordistik, 29 (2), 167-181.

Muylle, C. (2011), Communicatieleer. Berchem.

Oomkes, F.R. (2000), Communicatieleer. Amsterdam/ Meppel.

Pytel, W.A. (2003), Identyfikatory semantyczne tekstów specjalistycznych, (w:) J. Lukszyn (red.), Języki Specjalistyczne 3. Lingwistyczna identyfikacja tekstów specjalistycznych, Warszawa, 59-73.

Van Veelen, A. (2009), If we land in Chicago... Taal in het werk: de stewardess, (w:) Onze Taal 7/8, 78. jaargang, juli/ augustus 2009, 192-194. 